\title{
CRAFTING ANTI-TERRORISM LAW IN MALAYSIA: STRIKING A DELICATE BALANCE BETWEEN NATIONAL SECURITY AND PERSONAL LIBERTY
}

\author{
Ho Peng Kwang* \\ Johan Shamsuddin Sabaruddin ${ }^{* *}$ \\ Saroja Dhanapal $^{* * * *}$
}

\begin{abstract}
The sudden rise of this radical terror group calling themselves the Islamic State in Iraq and the Levant (ISIL) and the brazen show of decapitation of their captives have sent shock waves across the globe. This prompted the United Nations Security Council to adopt Resolution 2178 calling for its members to take preventive counterterrorism measures to contain the spread of this radical ideology propagated by ISIL. Malaysia in responding to this call, has passed and enacted the Prevention of Terrorism Act, 2015 (POTA) despite receiving much criticism that POTA has eroded fundamental human rights, in particular, the right to one's liberty. This article examines the challenges faced by the government in balancing between national security and personal liberty when crafting POTA. The article shows that equilibrium is hard to achieve between the two competing rights and thus has become disproportionate by looking at the POTA itself. The article concludes Malaysia's counterterrorism strategy prioritises national security over basic human rights, which clearly is abhorrent to the rule of law and that in fact, the threat posed by terrorism could have been exaggerated by the government in their efforts to fight terrorism as there are many other threats to life which call for more attention than the threat of terrorism itself.
\end{abstract}

Keywords: terrorism, counter-terrorism, POTA, human rights, national security.

Ph.D. Candidate, Faculty of Law, University of Malaya, email: richo@siswa.um.edu.my.

** Associate Professor, Faculty of Law, University of Malaya, email: johans@um.edu.my.

*** Senior Lecturer, Faculty of Law, University of Malaya, email: saroja.dhanapal@um.edu.my. 


\title{
MENGUBAL UNDANG-UNDANG ANTI KEGANASAN BARU DI MALAYSIA: MENGIMBANGI KERUNCINGAN DI ANTARA KESELAMATAN NEGARA DAN KEBEBASAN PERIBADI
}

\begin{abstract}
ABSTRAK
Kemunculan kumpulan pengganas radikal yang memanggil diri mereka negara Islam Iraq dan Levant (ISIL) di Syria telah menimbulkan satu kejutan besar kepada masyarakat seluruh dunia apabila kumpulan pengganas ini tidak teragak-agak untuk memaparkan proses pemancungan kepala mangsa yang ditawan oleh mereka secara terbuka. Perbuatan mereka ini telah mendorong Majlis Keselamatan Bangsa-bangsa Bersatu meluluskan Resolusi 2178 dan menyeru kepada ahli-ahlinya untuk mengambil langkahlangkah pencegahan keganasan selain dari membendung penyebaran ideologi radikal yang dilaungkan oleh ISIL. Malaysia, bertindak atas resolusi tersebut telah meluluskan undang-undang pencegahan anti-keganasan, 2015 (POTA) walaupun menerima banyak kritikan bahawa POTA telah menghakis hak-hak asasi manusia: iaitu hak kebebasan peribadi. Artikel ini akan meneliti cabaran yang dihadapi oleh pihak kerajaan dalam mengimbangi antara isu keselamatan negara dan kebebasan peribadi dalam melaksanakan undang-undang POTA. Makalah ini akan menunjukkan bahawa keseimbangan adalah sukar untuk dicapai antara dua hak yang bersaing dan dengan itu, ketidakseimbangan berlaku dengan melihat POTA itu sendiri. Makalah ini akan menyimpulkan bahawa strategi untuk membendung keganasan mengutamakan keselamatan negara berbanding dengan hak-hak asasi manusia di mana ia adalah satu penghinaan kepada nilai undang-undang yang sedia ada. Malah, ancaman yang ditimbulkan oleh keganasan mungkin telah dibesar-besarkan oleh pihak kerajaan dalam usaha mereka untuk menentang keganasan kerana terdapat banyak ancaman lain dalam kehidupan harian yang sepatutnya di beri perhatian yang lebih daripada ancaman keganasan itu sendiri.
\end{abstract}

Kata kunci: keganasan, anti keganasan, POTA, hak asasi manusia, keselamatan negara. 


\section{INTRODUCTION}

After more than a decade, the memory of the $9 / 11$ massacre has faded into oblivion until the world was awakened again by the turmoil perpetrated by an insurgent group calling themselves the Islamic State in Iraq and the Levant (ISIL) in the Middle East. The brutal beheading of photojournalist James Foley by ISIL, broadcasted live via videos on the YouTube.com has provoked the human desire around the world to retaliate against such barbaric act. ${ }^{1}$ Many beheaded victims were western captives and slaughtered by ISIL if their demand for ransoms were not fulfilled by their respective governments. The brutality portrayed brazenly by the group in the social media is unacceptable in our contemporary society. ISIL social media propaganda attracted not only local new recruits but also foreign sympathisers worldwide to join them. ${ }^{2}$ Some members of the ISIL are also talented in internet technology which made their recruitment drive much easier by using social media platform such as Twitter and Facebook to entice new recruits from everywhere around the world. The success of IS's recruitment drives was further heightened by their self-declaration of a new Islamic Caliphate and their consecutive military victories over their enemies. ${ }^{3}$

Despite the clarion call by the United Nation (UN) Security Council under Resolution $2178^{4}$ for member states to prevent the continual recruitment drive by ISIL, however, according to published news, in the past 12 months, the number of foreign recruits by ISIL has in fact doubled. ${ }^{5}$ Malaysia, in responding to Resolution 2178 enacted the Prevention of Terrorism Act 2015 (POTA). After the 9/11 attacks on the American soil, President Bush also signed anti-terror laws like the USA Patriot Act 2001 (USPA) to keep the nation safe

$1 \quad$ BBC. "Foley Beheading Video Shocks the World, Obama Says." BBC Middle East (BBC News), August 20, 2014. http://www.bbc.com/news/world-middleeast-28867627.

2 "Working Papers \& Publications," accessed February 3, 2017, http://www.nber.org/digest/jun16/w22190.html.

3 Scott Gates and Sukanya Podder "Social Media, Recruitment, Allegiance and the Islamic State." Perspectives on Terrorism, 9 (4) (2015): 107-116.

4 Resolution 2178 (2014). n.p., 2014. Accessed February 3, 2017, http://www.un.org/en/sc/ctc/docs/2015/SCR\%202178_2014_EN.pdf.

Accessed February 3, 2017. http://www.nytimes.com/2015/09/27/world/middleeast/thousands-enter-syria-tojoin-ISIL-despite-global-efforts.html. 
and free. ${ }^{6}$ However, after more than a decade the American people have now realised that the sweeping new powers under the USPA have curtailed the state's judicial powers. In short, the American peoples felt they have been short-changed by their government in relinquishing some of their civil rights, in particular, the right to personal freedom.

Hence, this article puts forward the claim that personal liberty is essentially a fundamental human right and it should not be ignored or suspended in exchange for national security considerations. Further, can the terrorism threat become so critical and more real than any other threat to lives that justify having the anti-terror laws of farreaching effect? Some scholars like Wilkinson ${ }^{7}$ and Heymann ${ }^{8}$ emphasised that in any democratic regime, democracy and civil liberties must be upheld whether in wartime or in peacetime, but for the government, national security overrides those core aspects of fundamental human rights. Even assuming the government is right to prioritise national security over the other essential human rights in battling terrorism, it does not necessarily mean our country will be much safer as Benjamin Franklin once said: "Those that can give up essential liberty to obtain a little temporary safety deserve neither liberty nor safety." 9

6 "H.R.3162 - 107th Congress (2001-2002): Uniting and Strengthening America by Providing Appropriate Tools Required to Intercept and Obstruct Terrorism (USA PATRIOT ACT) Act of 2001," October 26, 2001, accessed January 23, 2017, https://www.congress.gov/bill/107th-congress/house-bill/3162.

7 Paul Wilkinson, Terrorism Versus Democracy: The Liberal State Response, (London: Routledge, Taylor \& Francis, $3^{\text {rd }}$. ed., 2011), 115, pointing out that "most democratic states which have experienced prolonged and lethal terrorist campaigns of any scale within their borders have at some stage introduced special anti-terrorist measures aimed at strengthening the normal law in order to deal with a grave terrorist emergency."

$8 \quad$ Philip B. Heymann, Terrorism and America: A Common Sense Strategy for a Democratic Society, (Cambridge: The MIT Press, 2000), 16.

9 In 1755 (Pennsylvania Assembly: Reply to the Governor, Tue, Nov 11, 1755), Franklin wrote this phrase; accessed January 23, 2017, https://www.washingtonpost.com/news/volokhconspiracy/wp/2014/11/11/liberty -safety-and-benjamin-franklin/?utm_term=.d7ee4707db2d. 


\section{DILEMMA IN DEFINING THE RHETORIC OF TERRORISM}

Today, we are facing a different threat to global peace and security. Unlike terrorism of the past, some scholars argued that we are now confronting a "new" kind of terrorism. ${ }^{10}$ However, scholar like Crenshaw has a differing view. She claimed terrorism today is "not fundamentally or qualitatively new phenomenon, but grounded in an evolving historical context. Much of what we see now is familiar, and the differences are of degree rather than kind." "With the world's big political power in play today, the definition of what is terrorism and what is not becoming a rhetorical concept for many nations. So far, there is no unanimity on the common meaning of terrorism that is universally accepted. An under-inclusive definition may expose citizen vulnerable to harm because the law does not apply when it is needed. Whereas an over-inclusive definition can mean that the extraordinary new powers given to the enforcement agencies may be applied too broadly. As a result, it can undermine human rights and enable ordinary criminal acts to be labelled as terrorism.

While Resolution 2178 adopted by the UN Security Council required states to take immediate action to counter terrorism, it did not spell out the meaning of terrorism which left the states bewildered in drafting their own definitions. This poses a serious subjectivity problem as the concept of terrorism is a much-contested term. While some people may see an act as a terrorism offence, others can view it as a struggle for liberation which is justifiable. To distinguish a terrorist' from a 'freedom fighter' can be very tricky because it depends on how their political sympathisers view their struggles. If they like the goals of the freedom fighter, then he or she is not a terrorist and vice-versa. The classic example to look at was the struggle by the late Nelson Mandela, a Nobel Peace Prize winner. The

10 See Bruce Hoffman, Inside Terrorism (New York: Columbia University Press, 1998), 19; Daniel Benjamin and Steven Simon, The Age of Sacred Terror: Radical Islam's War Against America (New York Random House, 2003), xii; Walter Laqueur, The New Terrorism: Fanaticism and the Arms of Mass Destruction (New York: Oxford University Press, 1999), 90 and Ian O. Lesser, et al., Countering the New Terrorism (Santa Monica: The Rand Corporation, 1999), 86.

11 Martha Crenshaw, "The Debate over New vs. Old Terrorism." Values and Violence (2009): 117-136. 
late Mandela was labelled as a terrorist by the US government ${ }^{12}$ and the $\mathrm{UK}^{13}$ during his fight against apartheid in South Africa.

When defining what tantamount to an act of terrorism, the term 'insurgency' or 'guerrilla warfare' has been alluded to terrorism activities interchangeably. ${ }^{14}$ Although the strategies or tactics adopted by the guerrillas and insurgents appear similar to the terrorists, they are different in certain ways. Hoffman explained that guerrillas run like a military unit and are larger in number, although with the insurgents, they may have similar characteristics, except they adopt different tactics and strategies, for example, hit-and-run after achieving their targets. Hoffman further distinguishes between guerrilla groups, insurgents and terrorists as follows:

Terrorists, however, do not function in the open as armed units, generally do not attempt to seize or hold territory, deliberately avoid engaging enemy military forces in combat, are constrained both numerically and logistically from undertaking concerted mass political mobilization efforts, and exercise no direct control or governance over a populace at either the local or national level. ${ }^{15}$

Meanwhile, Schmid and Jongman ${ }^{16}$ provide a comprehensive list of useful guides to define terrorism. From the list of 109 different terrorism definitions examined, they used percentages to find how often each component is used. In their findings, violence and force components were represented by $83.5 \%$, political was $65 \%$ and for fear and terror emphasised was $51 \%$. So, in describing terrorism, 'violence' and 'political' are the key components that are universally

12 "US Government Considered Nelson Mandela a Terrorist Until 2008," December 7, 2013, accessed February 3, 2017, http://www.nbcnews.com/news/other/us-government-considered-nelsonmandela-terrorist-until-2008-f2D11708787.

13 Andy McSmith, "Margaret Thatcher Branded ANC 'terrorist' While Urging Nelson Mandela's Release," The Independent - UK Politics (Independent), December 9, 2013, accessed January 23, 2017, http://www.independent.co.uk/news/uk/politics/margaret-thatcher-branded-ancterrorist-while-urging-nelson-mandela-s-release-8994191.html.

14 Rohan Gunaratna, "Review of Inside Terrorism by Bruce Hoffman (New York, Columbia University Press, 2006)," Journal of Democracy and Security 4 (2008): 312-313.

15 Ibid.

16 Alex P. Schmid and Albert J. Jongman, Political Terrorism: A New Guide to Actors, Authors, Concepts, Data Bases, Theories, and Literature (London: Transaction Publishers, 1988), 1-38. 
adopted in defining terrorism according to them. In a nutshell, their definition is as follow:

Terrorism is an anxiety-inspiring method of repeated violent action, employed by (semi)clandestine individual, group, or state actors, for idiosyncratic, criminal, or political reasons, whereby in contrast to assassination - the direct targets of violence are not the main targets. The immediate human victims of violence are generally chosen randomly (targets of opportunity) or selectively (representative or symbolic targets) from a target population, and serve as message generators. Threat and violence-based communication processes between terrorist (organization), (imperilled) victims, and main targets are used to manipulate the main target (audience(s), turning it into a target of terror, a target of demands, or a target of attention, depending on whether intimidation, coercion, or propaganda is primarily sought. ${ }^{17}$

On the other hand, James Lutz and Brenda Lutz came out with their less complicated definition as compared to Schmid and Jongman. They relied on the following criteria to build-up the definition of terrorism that is:

Terrorism involves political aims and motives. It is violent or threatens violence. It is designed to generate fear in a target audience that extends beyond the immediate victim of the violence. The violence is conducted by an identifiable organisation. The violence involves a non-state actor or actors as either the perpetrator, the victim of the violence or both. Finally, the acts of violence are designed to create power in situations in which power previously had been lacking (i.e. the violence attempts to enhance the power base of the organisation undertaking the actions). ${ }^{18}$

The most distinctive aspect of the above definition is that it carries the word "civilian," unlike some alternative definitions. For instance, Boaz Ganor produces a simple definition claiming that "terrorism is the deliberate use of violence aimed at civilians in order to achieve political ends." ${ }^{19}$ Without the word "civilian", it raises ambiguity on

\footnotetext{
17 Ibid, 28.

18 James M. Lutz and Brenda J. Lutz. Global Terrorism. (London: Routledge, 2013), 322.

19 Boaz Ganor, "The Relationship between International and Localized Terrorism," accessed February 3, 2017, http://www.jcpa.org/brief/brief004-26.htm.
} 
the type of victims targeted by the terrorists. Meanwhile, Anthony Richards in his article "Conceptualizing Terrorism" believes that:

\begin{abstract}
[A] comprehensive (and more honest) definition of terrorism needs to incorporate the possibility of terrorism that one might sympathise with or even endorse as well as 'bad terrorism' an international approach to the phenomenon arguably should reflect this. ${ }^{20}$
\end{abstract}

Thus, his brief definition of terrorism is as follows:

Terrorism is the use of violence or threat of violence with the primary purpose of generating a psychological impact beyond the immediate victims or object of attack for a political motive. ${ }^{21}$

Following the various definitions of terrorism propounded by the above scholars, it can be summed up that the terrorists' aim is to extend territorial power geographically and to promote their political agendas. To reach these objectives, they have selected their victims randomly to instil a psychological fear on their victims.

When Malaysia responded to Resolution 2178, the new Prevention of Terrorism Act, 2015 (POTA) was enacted. Under the Malaysian POTA, the term 'terrorist act' was cross-referred to section 130 B (2), Chapter VIA, of the Penal Code. According to the Penal Code, 'terrorist act' means an act or threat of action where "the act is done or the threat is made with the intention of advancing a political, religious or ideological cause" and "the act or threat is intended to intimidate the public or a section of the public or to influence or compel the Government of Malaysia or the Government of any State in Malaysia, any other Government, or any international organisation." ${ }^{, 22}$ Further, in sub-section (3) it provides for any harm or damages inflicted while committing the terrorist act. ${ }^{23}$ It is interesting to note that there are exemptions under Section 130B (4) where a political protest or industrial action is not considered as a terrorist act if it does not intend harm such as a serious risk to health and safety of the public or a section of the public. Such exception does not exempt legitimate forms of protest. For a protest to fall outside the ambit of

\footnotetext{
20 Anthony Richards, Conceptualizing Terrorism, (Oxford: Oxford University Press, 2015), 146.

21

Ibid.

See s.130 (B) (2) (b) and (c) of the Penal Code.

See s.130 (b) (3).
} 
the law, the government just needs to show that the conduct was intended to create a serious risk to the health or safety of the public or a section of the public.

However, the point to make here is that in seeking to prevent terrorism, the government must be careful not to suppress legitimate dissent under the disguise of national security. Terrorism law must also be clear enough leaving no room for advancing the myriad of interpretation. This is even more significant when the punishment provided in the Penal Code is severe for suspected terrorist activities. For example, under Section 130J (1) (b) of the Penal Code, if anyone is found guilty of supporting terrorist acts, he or she can be liable to a maximum imprisonment of 30 years or life imprisonment or a fine including forfeiture of assets.

This key issue of definition is significant in determining who the state will consider as a terrorist and who will be subjected to the strict laws. In the absence of an unambiguous definition, the cumulative effect will diminish the protection of individual rights and the sanction of harsher penalties that are concomitant with the designation of "terrorism".

\section{NATIONAL SECURITY CONSIDERATION}

In modern democratic societies today, there are two competing issues that trigger many controversial debates between the government and the human rights groups. The central theme is how to balance the protections of citizen's personal liberties against national security during a state of emergency. While the state owes a moral obligation and duty to protect the safety and the well-being of their citizens, in reality the equilibrium between the two competing issues is a big challenge for the state. Sometimes the state can play the opposite role as a threat to their own people by legislating laws under the disguise of crime prevention. This is observed when a state has widened their power arbitrarily with the enactment of new anti-terror laws. In Malaysia, there is already reason to suspect the government of using counter-terrorism laws like the new POTA to undermine the fundamental legal rights such as the right to legal counsel. ${ }^{24}$

24 Section 10(6) of the POTA, 2015. 
Under the preventive laws on terrorism, the most controversial aspect is when a person is detained for suspected terrorist activities without first committing the act. Whether this pre-charge detention is considered as a legitimate deprivation of personal liberty depends on how a state views such threat. To prove the legitimate purpose taken by the State, it is always linked to national security considerations or crime prevention. Therefore, the contention here is whether such action taken can be questioned and if so, who is the one to question it? What happens if the government made the wrong assessment of the threat or risk to national security? De Londres and Davis pointed out that:

...[T]here are three responses to the limitation of personal liberties resulting from Executive power during times of violent terrorist related emergencies: (1) trust the Executive to behave responsibly and lawfully; (2) rely on the Legislature and the popular democratic processes to force the Executive to behave responsibly and lawfully and minimize judicial intervention; or (3) call on the Judiciary to intervene and restrict unlawful behaviour produced by the Executive, the Parliament or both acting together. ${ }^{25}$

Along similar lines, Ramraj argues that:

For threats of national security, the Executive, with the advice of the security intelligence community and other security experts within the bureaucracy is in a much better position to assess and respond to the risk of terrorism than the public, the legislature or the judiciary. When it comes to risk assessment, experts, particularly in their area of expertise are more likely than ordinary people to be right. ${ }^{26}$

If following Ramraj's argument, it is evident that the government would be in the best position to decide and assess on matters involving national security. However, the underlying arguments advanced by the above scholars were rejected by human rights

25 F. de Londras and F. F. Davis, "Controlling the Executive in Times of Terrorism: Competing Perspectives on Effective Oversight Mechanisms," Oxford Journal of Legal Studies, 30 (1) (2010): 19-47.

26 Victor V. Ramraj, "Terrorism, Risk Perception and Judicial Review," Global Anti-Terrorism Law and Policy (2005): 116. 
advocates such as Human Rights Watch. ${ }^{27}$ They cannot accept that there is a need to sacrifice one's personal liberty over national security considerations because the government in taking the purportedly legitimate steps in counter-terrorism could be objectively wrong in their assessment of the risk factors or being driven by some other ulterior motive. To date, the history of preventive detention laws in Malaysia revealed grave human rights violations linked to their practice by the government. For example, the previous draconian Internal Security Act (ISA) 1960, originally meant to counter communist insurgency in the past, has been used against political dissents, NGOs, and student activists in the infamous 'Operation Lalang ${ }^{28}$ until it was repealed lately. It is also feared that in relation to preventing terrorism, preventive detention featured in POTA can be a convenient tool for the government for any illegal purpose just like how ISA was indiscriminately applied during the Operation Lalang. ${ }^{29}$ The way the preventive law operates hinge on future predictions of an imminent threat to national security and practically speaking, it is an impossible task to test the degree of harm or danger as it is yet to occur. ${ }^{30}$

Next, this article shall examine the various counter-terrorism strategy adopted by the state and why it is said to have breached human rights, in particular, the right to personal liberty. In the study of national counter-terrorism strategy, there are at least two known models identified by Bhoumik. ${ }^{31}$ They are the 'criminal justice' and 'intelligence' models. He argues that preventive detention fits firmly

27 BBC, "Malaysia Passes Controversial Anti-Terror Bill," BBC Asia (BBC News), April 7, 2015, http://www.bbc.com/news/world-asia32194636?OCID=twitterasia.

28 "What Everyone Should Know about Operasi Lalang," January 2012, accessed February 3, 2017, http://www.malaysiandigest.com/archived/index.php/25features/commentary/18552-what-everyone-should-know-about-operasilalang.html.

29 “Anti-Terrorism Bill Passed in Parliament after Long Debate," The Star Online, April 7, 2015, accessed February 3, 2017, http://www.thestar.com.my/news/nation/2015/04/07/anti-terrorism-bill-passedin-parliament-after-long-debate/.

30 Michael Louis Corrado, "Punishment and the Wild Beast of Prey: The Problem of Preventive Detention," The Journal of Criminal Law and Criminology, 86 (3) (1996):778-814.

31 Arunabha Bhoumik, "Democratic Responses to Terrorism: A Comparative Study of the United States, Israel, and India," Denv. J. Int'l L. \& Pol'y 33 (2004): 285. 
within the 'intelligence model' of counter-terrorism strategy because it is proactive rather than reactive, with an emphasis on preventive measures and intelligence to infiltrate terrorist organisations and to thwart potential terrorist acts. As a preventive measure, under the intelligence model, terrorism is not viewed primarily as a criminal activity, but rather as a threat to the security of the state. Therefore, it can serve a legitimate purpose within the 'intelligence model' because: (a) Preventive detention is to thwart imminent terrorist acts or to preserve evidence relating to terrorist acts, not for criminal prosecution per se; (b) To achieve its purpose, preventive detention has a lower threshold that is required for a criminal arrest. Lesser facts are required to justify detention, allowing investigative and policing authorities to intervene at an earlier time than the criminal law would otherwise allow; (c) Preventive detention relies on lesser evidence than the ordinary criminal law, and for that reason, it overcomes difficulties relating to getting evidence concerning a terrorist charge.

In contrast, according to the 'criminal justice' model, terrorism is treated as a crime. The model provides for the capture and prosecution of a suspect after a terrorist act is committed. As crime must have an act (actus reus), the criminal justice model depends on prosecution after the fact has taken place, making it reactive as opposed to proactive. ${ }^{32}$ This includes all specified crimes as defined in the statute with the use of police force to investigate the breach of the law and the determination of guilt in a public trial. ${ }^{33}$

The two models fostered by Bhoumik seem to suggest that terrorism is an extraordinary crime and thus, under the intelligence model, it casts away all procedural rules and relaxes the evidential burden. However, the intelligence model suffers from criticism for lack of transparency and can have potential for abuses. The risk of arbitrary detention also raises concerns that preventive law contravenes international human rights law especially the right to liberty. In contrast, by using the criminal justice model, it has the advantage of the judiciary providing safeguards from being abused by the administrative, of any orders given under the preventive detention.

From the foregoing discussion, perhaps the Malaysian POTA was crafted following the 'intelligence model.' Preventive detention under the Malaysian POTA operates prospectively in a way the criminal law

Ibid., 296.

Ibid., 298-99. 
does not. An individual can be detained without probable cause or without future prosecution for up to two years. ${ }^{34}$ And on the expiry of the two years, the detention can be renewed for another two years. ${ }^{35}$ Moreover, the government may detain a person even if such person has not committed an offence or if there is insufficient evidence for criminal charges against such person. The lower threshold of evidentiary burden required under the preventive law is because the difficulties in prosecuting suspected terrorists due to inadmissible intelligence information, the frustrations of interrogation of terrorists trained to resist standard interrogation techniques and the fear of witnesses in testifying in terrorist trials. ${ }^{36}$ Further justification of preventive detention according to Seibert-Fohr ${ }^{37}$ is that:

In a number of States, argument has been raised that they are not able to provide within a short period of time enough for evidence for the courts to uphold the arrest on criminal charges. This led some States, such as the United Kingdom and the United States to use preventive or administrative detention in their counter-terrorism efforts... ${ }^{38}$

The difficulties of gathering enough evidence in terrorism cases are also hindered by the transnational nature of terrorism where coordination between governments and law enforcement agencies restrains an effective investigation. This is further compounded by States lacking capability or the political will to fight terrorism within their territories. Therefore, based on the earlier observation by Fohr, the need for early police intervention was understood as one of the principal justifications for relying on preventive detention law in Malaysia's counter-terrorism strategy. It has the effect of 'buying more time' for investigation and intelligence gathering. Furthermore,

\footnotetext{
34 Section 13(1) of POTA, 2015.

35 Section 17(1) of POTA, 2015.

36 Douglas Cassel, "Redefining International Criminal Law: New Interpretation and New Solutions: Criminal Law: Pre-trial and Preventive Detention of Suspected Terrorists: Options and Constraints under International Law," J. Crim. L. \& Criminology, 98 (2008): 811-1501.

37 Anja Seibert-Fohr, "The Relevance of International Human Rights Standards for Prosecuting Terrorists," in Terrorism as a Challenge for National and International Law: Security Versus Liberty? eds., Walter, Voneky, Roben, Schorkopf, (SSRN: 2004), 125-163, accessed February 3, 2017, SSRN: http://ssrn.com/abstract=1430877. 
in preventing a terrorist attack, if police intervention is too late, the impacts of terrorist attacks could well occur with dire consequences which can devastate a large segment of society based on the current trend of terrorist attacks.

Primarily, this is the dilemma facing the democratic government today in balancing national security over personal liberty when implementing counter-terrorism strategies.. It is noteworthy that in Malaysia, there are already other laws in place to deal with security threats before the enactment of POTA, that is the Security Offences (Special Measures) Act, 2012 (SOSMA), Prevention of Crime Act, 1959 (POCA) and the relevant provisions of the Penal Code (Chapter VIA). With an array of security legislation to apply by the government, the question is whether POTA is necessary or is it an overzealous action by the government looking for broad power?

\section{PERSONAL LIBERTY CONSIDERATION}

The roots of personal freedom and the protection against arbitrary detention can be traced to the $13^{\text {th }}$ century in England - the medieval charter called Magna Carta 1215. Article 39 of the Magna Carta provides that:

No freeman shall be taken or imprisoned or disseized or outlawed or exiled or in any way harmed - nor will we go upon or send upon him - save by the lawful judgment of his peers or by the law of the land. $^{39}$

Since then, the Magna Carta became the symbol of the prohibition on arbitrary power. Today, all nations are guided by the Universal Declaration of Human Rights for the protection of personal liberty. Although the Universal Declaration is a mere expression of collective opinion and therefore not legally binding, the International Covenant on Civil and Political Rights (ICCPR), in particular Article 9(1), that provides for the right to personal liberty and security, freedom from arbitrary arrest and detention, binds 168 States parties. The right in Article 9(1) entails other procedural safeguards under Article 9(2) to (5) such as:

39 Statutes of the Realm 6-7 (1810) UK, art.39. 
"(2) the right to be informed as to the reasons for arresting and detention, and of any charges laid; ${ }^{40}$

(3) the right to be promptly brought before a judge or other judicial officer to exercise judicial power and the right to be entitled to trial within a reasonable time or to release, ${ }^{41}$

(4) the right to take proceedings before a court without delay on the legality of detention and order release if the detention is not lawful; ${ }^{42}$

(5) the right to compensation if there has been unlawful arrest or detention." 43

It is observed here that Article 9(4) ICCPR enshrined the writ of habeas corpus. Now, having briefly examined the legal framework of personal rights as provided under Article 9, the inherent issue of concern is that in crafting counter-terrorism laws by member states, has any of the core fundamental rights in particular, right to liberty is being considered? What is Malaysia's position regarding compliance with the international treaty like the ICCPR? It is noteworthy that Malaysia is neither a signatory nor a party to the ICCPR. How then is the Malaysian government going to reconcile their preventive detention law with the rights promulgated under Article 9(1) ICCPR?

In fact, Malaysia adopts the dualism approach as far as international law is concerned. What this means is that international law and municipal law are two distinct systems of law functioning in its own sphere. The rules of international law can only work in our local legal system provided they are enacted by the Parliament. As an example, in the case of $M B f$ Capital Bhd. \& Anor $v$ Dato Param Cumaraswamy,${ }^{44}$ the defendant was appointed by the United Nations as a Special Rapporteur on the Independence of Judges and Lawyers. When he was accused of defaming the plaintiff, he relied on section 22 (b), Article VI of the Convention on the Privileges and Immunities of the United Nations, 1946 to claim immunity as his defence.

\footnotetext{
40 ICCPR, Article 9(2).

41 Ibid., Article 9(3).

42 Ibid., Article 9(4).

43 Ibid., Article 9(5).

44 [1997] 3 CLJ 927.
} 
However, the High Court took the view (inter alia): (1) that the United Nation Secretary-General's Certificates issued to define the privileges and immunities accorded to the defendant was merely an opinion; and (2) the issue of immunity was not capable of decision in a summary manner, and therefore, the matter ought to be resolved at the full hearing of the suit. The Court of Appeal subsequently endorsed this view. ${ }^{45}$

Privileges and immunities came up again in another defamation suit involving the same Special Rapporteur in Insas Bhd \& Anor $v$ Dato' Param Cumaraswamy. ${ }^{46}$ However, by this time the International Court of Justice (ICJ) has already given an advisory opinion on the position of Dato' Param as Special Rapporteur. The ICJ ${ }^{47}$ held that Dato' Param was qualified to claim privilege from legal process for the words uttered by him during his term of office as a Special Rapporteur and the Malaysian government was obliged to notify the courts of the ICJ's findings. In the wake of the rulings on Dato' Param, consequently, the Malaysian High Court in Insas's case gave legal effect to the ICJ's advisory opinion. Ensuing from the decision of Insas, we can articulate that it is laudable for the Malaysian Court to give binding effect to ICJ's advisory opinion.

However, it is to be admitted that the established approach of the the Malaysian Courts is 'dualism.' A case in point is Than Siew Beng \& Anor v. Ketua Pengarah Pengarah Jabatan Pendaftaran Negara \& Ors ${ }^{48}$ where Justice Asmabi held that:

International treaties do not form part of the law in Malaysia unless such treaties have been incorporated into the municipal law. The court would refer to these international norms only if the same had been incorporated by way of municipal law.

In another development, the High Court was asked to consider the provisions of the Universal Declaration of Human Rights ('UDHR') in the case of Lim Jen Hsian \& Anor v. Ketua Pengarah Jabatan Pendaftaran Negara \& Ors. ${ }^{49}$ The court held that:

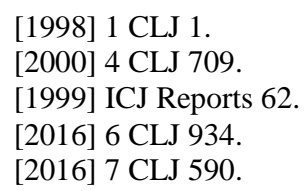


The UDHR is applicable in Malaysia only to the extent that it is not inconsistent with the Federal Constitution. The provisions of the UDHR must be read together with s. 4(4) of the Human Rights Commission of Malaysia Act 1999. Unlike some other constitutions in other jurisdictions, the Federal Constitution does not impose on the Malaysian courts to take cognisance of international human rights laws in any of its provisions.

From the study of the above-decided cases, we can, therefore, conclude that the Malaysian courts will only apply international treaties provided the treaty referred to has been converted into the national law by means of an Act of Parliament. Admittedly, the Malaysian courts do not take cognisance of international human rights laws, but for the subsequent discussion that follows, this article will examine to what extent the Malaysian POTA has fared if to compare with the international norms and practice.

Under the Malaysian POTA, a suspected person can be detained without trial. The issue for discussion here is, what test shall apply to make it legitimate and compatible with the principles of international justice? Or to what extent this detention order is in line with the international human rights standard of practice under the international treaty? In the case of $C v$ Australia,${ }^{50} \mathrm{C}$ was detained without a valid entry permit in the immigration detention pending removal from Australia. The Human Rights Committee noted that in relation to asylum seekers, all applications to enter and remain in Australia are thoroughly considered on a case to case basis. The Committee held that the likelihood for the asylum seekers to disappear if released into the community is there. Therefore, such persons ought to be detained. As such:

The policy of detaining unauthorised arrivals is reasonable, proportionate and necessary in all of the circumstances under such cases...were not arbitrary, as they were justifiable and proportionate on the grounds outlined above. ${ }^{51}$

The Human Rights Committee has emphasised that under Article 9(1) of the ICCPR, the concept of proportionality ought to be observed. In Danyal Shafiq v Australia, the Human Rights Committee

50 C v Australia (900/1999) 13 November 2002, UN Doc CCPR/C/76/D/900/1999.

51 Ibid. 
referred to $C v$ Australia and held that the main test [whether such detention is arbitrary] is to determine if the detention is reasonable, proportionate, justifiable and appropriate in the circumstances. ${ }^{52}$ Article 9(1) propounds the view that it requires the consideration if a particular measure is for a legitimate aim and purpose. If so, whether such measure is essential to reach that purpose, having considered whether a less restrictive way is available as a choice to the measure in question. An analysis of major decisions on terrorism cases in the United States ${ }^{53}$ and the United Kingdom ${ }^{54}$ the principle of proportionality has played a key role in the disposition of each instance. Further, according to Nowak's explanation on proportionality as applied under Article 9(1) ICCPR,

Cases of deprivation of liberty provided for by law must not be manifestly unproportioned, unjust or unpredictable, and the specific manner in which an arrest is made must not be discriminatory, and must be able to be deemed appropriate and proportional in view of the circumstances of the case.

The foregoing discussion on interpreting Article 9(1) illustrates that 'proportionality' is, therefore, a question of balance which has been widely accepted internationally. By applying this understanding, this means that if a less intrusive measure had achieved the purpose of a preventive detention order, the scales would be unbalanced and disproportionate. This 'proportionality' principle has also been applied and well-received by the Malaysian court in Sivarasa Rasiah $^{56}$ although that case was unrelated to terrorism. The proportionality principle was reaffirmed recently in the case of Azmi Sharom ${ }^{57}$ where the Federal Court again reiterated the proportionality principle as laid down in Dr Mohd Hashim's case ${ }^{58}$ that the legislation or executive action must not only be objectively fair but

\footnotetext{
52 Danyal Shafiq $v$ Australia (1324/2004) 5 November 2004, UN Doc CCPR/C/88/D/1324/2004, para.4.10.

53 Rasul v Bush, 542 U.S. 466 (2004); Hamdi v Rumsfeld, 542 U.S. 507 (2004); Rumsfeld v Padilla 542, U.S. 426 (2004).

$54 \quad A(F C) v$ Secretary of State for the Home Department (2005) 2 AC 68

55 Manfred Nowak, UN Covenant on Civil and Political Rights: CCPR Commentary, (NP Engel, 1993), 27.

$56 \quad$ Sivarasa Rasiah v. Badan Peguam Malaysia \& Anor [2010] 2 MLJ 333.

57 PP v. Azmi Sharom [2015] 8 CLJ 921.

58 Dr. Mohd Nasir Hashim v. Menteri Dalam Negeri Malaysia [2007] 1 CLJ 19.
} 
must also be proportionate to the object sought to be achieved. What is germane to note here is that to challenge whether the preventive detention order is legitimate for its purpose, one has to adopt the 'proportionality test'.

Another point for consideration is that under international law, a "state of emergency" allows the government to suspend human rights guarantees under each of the international human rights instruments like the ICCPR. This exercise will entail an attempt to balance human rights obligations and the national interest. It is observed that Article 4(1) of ICCPR ${ }^{60}$ allows a state to declare a state of emergency whereby limited derogation is permitted. This begs the question whether the terrorism threat in Malaysia gives a good reason to pass emergency laws under Article $149^{61}$ of the Federal Constitution? A study of the ECHR's case of Lawless v Ireland (No $3)^{62}$ directly deals with this issue. In that case, the ECHR confirmed that under international law, terrorism could be the kind of emergency that would validate a declaration of a state of emergency. It went further to clarify the concept of a public emergency as being a situation of exceptional and impending crisis or danger involving the general public and being up a threat to the life of the community of which the State is composed. In the Greek case, the ECHR summarised the characteristic of a public emergency as follows:

(i) it must be actual or imminent;

(ii) its effects must involve the whole nation;

59 The International Law Association (ILA) adopted the "Paris Minimum Standards of Human Rights Norms in a State of Emergency" which contain the following prescription: "The existence of a public emergency which threatens the life of the nation, and which is officially proclaimed, will justify the declaration of a state of emergency. The expression "public emergency" means an exceptional situation of ISIL or public danger, actual or imminent, which affects the whole population or the whole population of the area to which the declaration applies and constitutes a threat to the organized life of the community of which the state is composed." Richard B. Lillich, "The Paris Minimum Standards of Human Rights Norms in a State of Emergency," American Journal of International Law, 79(4) (1985): 1072-1081.

60 "International Covenant on Civil and Political Rights," 1996, accessed February 3, 2017, http://www.ohchr.org/en/professionalinterest/pages/ccpr.aspx.

61 Article 149 of Federal Constitution empowers the Parliament to pass laws against subversion, any action prejudicial to public order etc.

62 No. 1/61, Judgment of July I, 1961, of the European Court of Human Rights accessed February 3, 2017, http://hudoc.echr.coe.int/eng?i=001-57518. 
(iii) the continuance of the organised life of the community must be threatened;

(iv) the crisis or danger must be exceptional in that the normal measures or restrictions permitted by the Convention for the maintenance of public safety, health and order are plainly inadequate. $^{63}$

Following the above proposition as laid down by the ECHR, perhaps the demand for "actual or imminent threat" includes state of emergency declared as a preventive measure, that is, to face possible imminent exceptional situations including the menace of terrorism. Accordingly, the Malaysian Government is justified in derogating fundamental human rights as provided under Article 5 (liberty of person), 9 (freedom of movement) and 10 (freedom of speech) of the Federal Constitution. Thus, it can be succinctly put that permissible variations are allowed but are limited. National security concerns do not justify a complete abrogation of rights. Any variation may need to be compensated as far as possible by an alternative safeguarding mechanism, usually in the form of judicial scrutiny or fair trial.

Malaysia, in response to the Security Council Resolution 2178, in a hurry introduced POTA by neglecting one's right to personal liberty. This holds true when POTA did not allow for judicial review of a detention order issued by the authority ${ }^{64}$ unless the decisionmaking body has acted ultra-vires the object of the Act. Only under such a limited circumstance that the court can interfere regardless of the ouster clause. ${ }^{65}$ Such a provision is a clear example of depriving the detainee to contest in court if there is any abuse by the authority. This merits the concern that the denial of due process is also objectionable to the rule of law traditions upheld by many democratic states.

As observed, most countries weaken their respect for the rule of law and liberties in wartime. According to Falk, ${ }^{66}$ what is ominous is

63 The decision can be found in "The Greek Case as reported in the Yearbook of the European Convention on Human Rights: The European Commission and European Court of Human Rights (1969), para.153.

64 Section 19(1) of POTA.

65 Kwang, Ho Peng, "The New Prevention of Terrorism Act 2015 (POTA): A legal commentary," Journal of Malaysian and Comparative Law, 43(1) (2016): 24.

66 Richard Falk, "Encroaching on the Rule of Law: Post-9/11 Policies within the United States," in National Insecurity and Human Rights: Democracies Debate 
the executive sensitivity to civil liberties, human rights and the rule of law and it is unlikely that judicial protection during wartime will be very effective except in extreme instances of abuse where the security justifications seem frivolous. This is further compounded in an atmosphere of national emergency when the executive branch purports to have superior secret knowledge that may not be shared, hence, there is a judicial reluctance to invalidate government policy by the court. ${ }^{67}$ The question is how are we to check if there is any abuse by the government.

The rule of law is to subject state power to rigorous checks to enforce the line between guilt and innocence and to hold government officials accountable to accept clear rules. However, these ideals mix uneasily with the strategies of the preventive model which demands wide executive discretion and avoiding questions of guilt or innocence (because no wrong has yet occurred). The problem starts when the rule of law insists on objective evidence of wrongdoing; the preventive detention model relies on predictions about future behaviour and secret evidence held by the government. Such predictions generally cannot be proved true or false and normally rest on questionable assumptions vulnerable to textual manipulation of the law. However, what matters most with a significant concern to many is whether the decision-making procedure under POTA has complied with the essence of the rights guaranteed and protected under the Federal Constitution.

\section{APPROACH FROM OTHER COMMONWEALTH JURISDICTIONS}

\section{United Kingdom}

For balancing national security of the state and personal liberty of its citizens, the situation in the UK differs slightly from Malaysia. In the UK, the Human Rights Act (HRA) 1998, which acts as a governing framework for human rights issues, are being applied broadly by the British Law Lords. Among the highlights found in the HRA 1998 that is worth noting are, for example, the UK's State Secretary is

Counterterrorism, ed. Alison Brysk and Gershon Shafir (California: Univ of 
empowered to declare any derogation from one of the rights under the ECHR ${ }^{68}$ Further, any public authority in the UK may not act in a manner incompatible with a European Convention right. ${ }^{69}$ 'Public authority' encompasses "a court or tribunal and a person certain of whose functions are functions of a public nature; however, it does not include Parliament or a person exercising functions in connection with the proceedings in Parliament. ${ }^{70}$

The stark contrast between the UK and the Malaysia is that the UK courts are vested with strong authority to declare any inconsistency under their HRA $1998^{71}$ whereas, in Malaysia, no judicial review is permissible ${ }^{72}$ even if there is a clear human rights violation. It is observed that where any executive act is found to be incompatible with any legal provision that touches on human rights, or freedoms, the result varies remarkably between the Malaysian and the UK way of handling it. Although section 3(2) of HRA 1998 disallows the judiciary in the UK to nullify any law at odds with ECHR, the court is vested with clear authority to declare any incompatibility. ${ }^{73}$ In $\operatorname{Re} M B$, for instance, the UK court held that the control orders issued under the Prevention of Terrorism Act 2006 were incompatible with liberty rights and the right to a fair trial under Article 6 of the ECHR. ${ }^{74}$

However, the making of a declaration of incompatibility under the HRA 1998 does not affect the validity, continuing operation and enforcement of any incompatible legislation should stand as an exceptional measure, only if a conflict between the HRA 1998 and other legislation, which make it incompatible and thus firming up the interpretative presumption under section $3 .^{75}$ The UK government has the choice of changing the offending law whenever a declaration of incompatibility is issued. Unless there are "compelling reasons" for the British Minister to make any corrective order by amending the law to remove the incompatibility, he may do so under the law. ${ }^{76}$

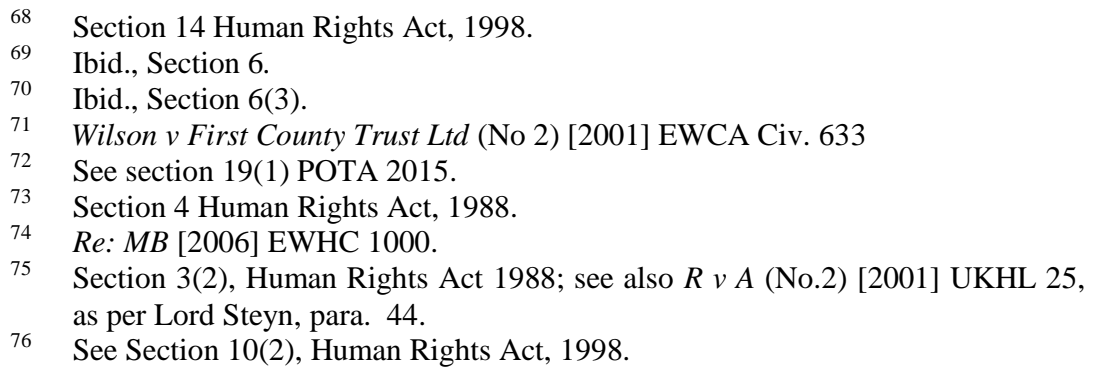

76 See Section 10(2), Human Rights Act, 1998. 
Apart from the above-mentioned provisions, section 8(1) of the HRA 1998 sets out a general power to the court to "grant such relief or remedy, or make such order within its powers as it considers just and proper" regarding violation of personal liberties by any public authority.

\section{India}

Much like Malaysia and the UK, India also confronts a similar quandary of trying to balance between protecting national security and safeguarding personal liberty in their efforts to counter terrorism. India, like Malaysia under Article $149,{ }^{77}$ has the power to pass security laws to safeguard its citizens from terrorist attacks and to keep peace and order. But one may query whether this state power has been invoked within the reasonable limits allowed under the Indian Constitution. The question of reasonableness is directed at the way such anti-terror laws are implemented by the government, whether fairly or unfairly invoked on its citizens. As to the standard of reasonableness, the answer lies in the heart of their constitutional framework to regulate the power of the state and to prevent any arbitrary incursion of personal liberty.

For example, freedom of speech, expression, peaceful association, and movement are enshrined in Article 19 of the Indian Constitution. However, the Indian government could enforce "reasonable restrictions" on such freedoms if it affects (inter alia,) the security of the state. ${ }^{78}$ Hence, in Ram Manohar Lohia v. State of Bihar ${ }^{79}$ the Supreme Court explained the concepts of "security of the State," "public order," and "law and order" by providing distinguishable clear examples to follow. A "law and order" situation occurs when two persons involved in a violent fight. On a bigger scale, if the fight is derived on an issue connected to groups of people from a community, and so it influences the community, then this befits a "public order" situation. As for threats to the security of the state, they make-up only a small circle within the public order and are usually insignificant.

Regardless of the explanation given by the Supreme Court in Lohia's case, the concepts of public order and national security

\footnotetext{
77 See Article 149 of the Malaysian Federal Constitution.

78 Article 19(2) of the Indian Constitution.
}

79 (1966) 1 SCR 709. 
continue to be vague. ${ }^{80}$ Further, in times of an emergency, the Constitution allows the suspension of Article 19 rights. Even though Article 22 safeguards protection on unlawful detention and arrest, it does not extend to individuals caught under the preventive detention laws. ${ }^{81}$ It is further observed that the Indian Constitution legalised preventive detention ${ }^{82}$ since the drafter of the Constitution could have anticipated that:

[T] here may arise occasions in the life of the nation when the need to prevent citizens from acting in ways which unlawfully subvert or disrupt the bases of an established order that may outweigh the claims of personal liberty. ${ }^{83}$

So, in the contest between the security of the state and individual rights protection in India, it has fostered much debate in their Parliament just like in Malaysia during the passage of POTA 2015. Among the common national security issues raised by both nations are the underlying arguments which focus on due process and the arbitrary preventive detention regime.

It is interesting to highlight here that although the right to life and personal liberty is safeguarded under Article 21 of the Indian Constitution, the exception is that it must be under the procedure established by law. However, the term 'procedure' is not clearly defined. In the landmark case of Maneka Gandhi v. Union of India, ${ }^{84}$ the Supreme Court tried to deliberate the term procedure judicially. The court took a decisive stand and held that the term 'procedure' ought to be construed that "all actions of the state must be right, just and fair, not arbitrary, fanciful or oppressive." Apparently, this landmark decision seems to be inconsistent with Article 22 that allows for preventive detention, the provisions for deprivation of personal liberty ${ }^{85}$ and the freedom of movement. ${ }^{86}$

In sum, anti-terrorism laws in Malaysia, the UK and India evoke a perpetual conflict between personal liberties and national security

80 K. G. Kannabiran, The Wages of Impunity: Power, Justice, and Human Rights. (New Delhi: Orient Longman, 2004), 83.

81 Article 22 (3) of Indian Constitution.

82 Ibid., Article 22 (4) - (7).

83 Rajbhar v. State of West Bengal (1975) 3 SCR 63, 70;

84 (1978) SCC 248.

85 Article 21 of Indian Constitution.

86 Ibid., Article 19 (1) (d). 
concern as highlighted above. The state disregards the adherence to the international law obligations and the domestic constitutional law when drafting anti-terror laws which may lead to a continued violation of human rights value. Admittedly, terrorism also encroaches upon human rights value by disrupting the security of the nations and its citizen. Hence, there are dilemma and challenges in balancing the two competing rights. However, it is strongly believed that to counter terrorism effectively, it should not be fought like what Mahatma Gandhi once said: "An eye for an eye only ends up making the whole world blind." 87

\section{IS THE FEAR OF TERRORISM OVERSTATED?}

When the Prime Minister of Malaysia tabled a white paper in Parliament on 26 November 2014 entitled: 'Towards Combating the Threat of Islamic State', it was claimed that the constant threat of ISIL propaganda, and its radical ideology in the Middle-East, can infiltrate into our country. ${ }^{88}$ It was reported that many of the Malaysian ISIL sympathisers already travelled to Syria to fight along with ISIL and some of them got killed. ${ }^{89}$ It was urged that on the basis of this fear, our country needs a new law specifically to combat such threat to our nation and to deter Malaysians from supporting such group. Despite the fear instilled by our government, this article argues that the act of terrorism in Malaysia presents an insignificant danger to life as compared to many other activities we do daily. According to a study by Wolfendale, ${ }^{90}$ the chances of motorists being killed in car accidents are greater than being killed in a terrorist attack even after 9/11. Malaysia encountered its first ever ISIL sympathisers attack in

87 "Mahatma Gandhi Quotes," 2001, accessed February 3, 2017, http://www.brainyquote.com/quotes/quotes/m/mahatmagan107039.html.

88 "Prime Minister's Office of Malaysia," 2015, accessed February 3, 2017, http://www.pmo.gov.my/home.php?menu=speech\&page=1676\&news_id=745\& speech_cat=2.

89 Farik Zolkepli, "Malaysian Militants Killed in Syria Airstrike," The Star Online, January 16, 2017. Accessed February 3, 2017. http://www.thestar.com.my/news/nation/2017/01/16/msian-militants-killed-insyria-airstrike-of-the-three-men-who-died-one-had-threatened-attacks-again/.

90 Jessica Wolfendale, "Terrorism, Security, and the Threat of Counterterrorism," Studies in Conflict \& Terrorism, 29(7) (2007):75-92. 
the suburb of Kuala Lumpur. ${ }^{91}$ Although there has been no record of major casualty caused by the attack, our government with great enthusiasm still thinks the abundance of counter-terrorism legislation like the SOSMA, the Penal Code (Chapter VIA), and POTA are all necessary to fight terrorism.

Supporters of the need of radical counterterrorism measures may acknowledge that although the danger of being slaughtered in a terrorist attack is not present yet, such future risk of terrorism can be massive in scale to warrant the suspension of one's freedom as a preventive step ahead of such catastrophic damage. Although it may be tricky to argue against any hypothetical possibilities, admittedly, an act of terrorism could instantly kill hundreds of thousands of innocent lives in the blink of an eye. On the other hand, does the inculcation of fear on its citizen justify a compromise of personal liberty by the government? While evaluating the probability of a potential threat is hard, equally, there is a lack of proof that terrorists main target is to slaughter many innocent lives at random. ${ }^{92}$

Further, the evidence that terrorists are planning massive acts of terrorism on our soil is slight, unlike other western or middle-eastern countries. This was confirmed by a recent report published by the UK Foreign Office, ${ }^{93}$ which shows that Malaysia is not even listed as the top ten countries with high terror threat rating. Even the Malaysian Deputy Home Minister ${ }^{94}$ concurred that:

They (ISIL) don't want to cause harm to the local population. This will be counter-productive to their own struggle. They want to focus on areas where there are a lot of foreigners and where unislamic activities thrive and at the same time hurt security forces.

Therefore, the argument that the terrorism threat in Malaysia is life threatening is hyped up as compared to any other threats to a human

91 "Cops Confirm Movida Bombing First Ever IS Attack in Malaysia," The Star Online, July 4, 2016, accessed February 3, 2017, http://www.thestar.com.my/news/nation/2016/07/04/movida-igp-confirm-isattack/.

92 Jessica Wolfendale, 75-92.

93 Oliver Smith, "Mapped: Terror Threat Around the World," The Telegraph, December 20, 2016, http://www.telegraph.co.uk/travel/maps-andgraphics/Mapped-Terror-threat-around-the-world/.

94 BERNAMA. "Berita Wilayah." 2017. Accessed February 3, 2017. http://www.bernama.com/bernama/state_news/news.php?id=1210348\&cat=ct. 
being, be it natural and man-made. Although our government has a moral obligation to guard the lives of citizens against any danger, in doing so, does it mean taking away certain basic legitimate human rights as a trade-off? Is the right to national security so important that the government can abnegate those rights? If the answer is in the affirmative, equally the government should have a similar moral obligation to reduce the danger of road accidents, street crime, and other life-threatening events even when doing so demands the restriction of our civil liberties. If terrorism portrays an insignificant threat than other real threats facing Malaysia as discussed above, what good does it serve by overstating the danger of terrorism and inculcate the unnecessary culture of fear on Malaysians during the passage of POTA in Parliament? In a recent development, the Royal Malaysian Police Counter-terrorism division's principal assistant director, Datuk Ayob Khan Mydin Pitchay, ${ }^{95}$ in a briefing to foreign diplomats in Malaysia also confirmed that the ISIL threats were "very much contained" now due to the significant efforts put up by the police. Thus, it is believed this containment is certainly not due to the efficacy of POTA.

\section{CONCLUSION}

The new anti-terrorism legislation known as POTA in Malaysia seems to have brought much contention, particularly the preventive detention provisions as highlighted above. Much of the contention raised was directed at the unfairness when an individual could face detention without trial for up to two years as a crime preventive measure taken by the government against would-be terrorists. However, in crafting the anti-terror law in Malaysia, the most critical consideration for the government would revolve around striking a delicate balance between one's personal liberties against the national security, in which case, equilibrium is hard to achieve as highlighted. Despite the dilemmas faced by the government, it is acknowledged

95 Ananya Roy, "Malaysia to Foreign Diplomats: Isis Threat Against Country 'Contained' for Now," Conflict (International Business Times UK), August 10, 2016, accessed February 3, 2017, http://www.ibtimes.co.uk/malaysia-foreigndiplomats-ISIL-threat-against-country-contained-now

1575276?utm_source=yahoo\&utm_medium=referral\&utm_campaign=rss\&utm _content=/rss/yahoous/news\&yptr=yahoo. 
that counterterrorism requires many compromises in the fundamental principles of legality. In fact, there is nothing wrong with prevention itself as a motive or a strategy particularly, in fighting terrorism. But, the right to one's liberty which is a corollary to the rule of law values should not be abandoned as a matter of principle as this is abhorred by citizens of democratic states.

To conclude, trying to craft an effective and all-inclusive preventive law against the threat of terrorism is not an easy task for the government. The important thing to note is, a nation abiding by the rule of law should observe the rule of law values and not regard it as an obstacle in their counter-terrorism campaigns. Although admittedly, individuals' liberties would be abrogated for the benefit of a larger societal good in fighting terrorism, the government ought to take cognisance of this important aspect which cannot be traded-off wholly or ignored in their counter-terrorism policy. 